УДК 332.135:001.82

DOI https://doi.org/10.32851/tnv-pub.2021.3.7

\title{
МЕТОДОЛОГІЯ ДОСЛІДЖЕННЯ ПРОЦЕСІВ МІЖРЕГІОНАЛЬНОЇ ІНТЕГРАЦІї
}

\author{
Корнієвський С.В. - кандидат наук з державного управління, \\ докторант кафедри державного управління та місцевого самоврядування \\ Національного технічного університету «Дніпровська політехніка» \\ ORCID: 0000-0001-5089-1006
}

У статті зазначено, що актуальність міжрегіональної інтеграції для підвищення ефективності політики регіонального розвитку зумовлена можливостями зміцнення економічних зв'язків між регіонами, оптимізації побудови інфраструктури на основі спільних иілей розвитку, зменшення фінансових витрат, мінімізаиії негативного впливу міжрегіональної конкуренції на просування регіонів у глобальному економічному просторі, об' $є$ нання потенціалів регіонів для реалізачії міжрегіональних інвестиційних проектів, більш ефективного використання спільних ресурсів, обміну прогресивним досвідом у сфері регіонального розвитку тощуо.

Акцентовано увагу на тому, щчо органами влади недостатньо використовуються можливості впливу на інтеграційні процеси, які мають суттєвий потенціал для підвищення ефективності політики регіонального розвитку, через що існує необхідність активізаиії наукових розвідок у иій сфері.

Автором поставлена мета - визначити методологічні складові частини дослідження проиесів міжрегіональної інтеграції.

Визначено, щзо у сучасних дослідженнях поняття інтеграції пов'язане зі зміцненням взаємозалежності та злагодженості елементів соиіальної системи, ї̈ основу становить міжсистемна взаємодія суспільно-політичної, сочіально-економічной, науково-технологічної, соиіокультурної сфер суспільного життя.

Встановлено, щзо особливою формою інтеграчії, обмеженої територіальними рамками, є міжрегіональна інтеграція.

На думку автора, методологічно міжрегіональна інтеграція має включати сутність, принципи, суб'єкти й об'єкти, головні фактори розвитку міжрегіональної інтеграиії, основні напрями, а також форми та механізми міжрегіональної взаємодї̈, у тому числі ї̈ інституиійно-правове забезпечення.

Зроблено висновки про те, щзо використання наведених методологічних складових частин міжрегіональної інтеграції має посісти належне місце у діяльності органів публічного управління з метою формування ефективної політики регіонального розвитку. Такий підхід сприятиме визначенню перспективних напрямів міжрегіонального співробітництва, становленню нових форм і механізмів міжрегіональної взаємодії та ін.

Ключові слова: інтеграція, міжрегіональна інтеграція, співробітництво, зв'язки, методологічні складові частини.

\section{Korniievskyi S.V. Metodology of research of interregional integration processes}

The article notes that the relevance of interregional integration to increase the effectiveness of regional development policy is due to the possibility of strengthening economic ties between regions, optimizing the construction of infrastructure based on common development goals, reducing financial costs, minimizing the negative impact of interregional competition on the global economic space. pooling the potential of regions for the implementation of interregional investment projects, more efficient use of common resources, exchange of progressive experience in the field of regional development, etc.

Emphasis is placed on the fact that the authorities do not make sufficient use of opportunities to influence integration processes, which are a significant potential for improving the effectiveness of regional development policy and therefore there is a need to intensify scientific research in this area.

The author aims to determine the methodological components of the study of interregional integration processes.

It is determined that in modern research the concept of integration is associated with strengthening the interdependence and coherence of the elements of the social system and its 
basis is the intersystem interaction of socio-political, socio-economic, scientific and technological, socio-cultural spheres of public life.

It is established that a special form of integration, limited by the territorial framework, is interregional integration.

According to the author, methodologically interregional integration should include the essence, principles, subjects and objects, the main factors of interregional integration, the main directions, as well as forms and mechanisms of interregional cooperation, including its institutional and legal support.

It is concluded that the use of the above methodological components of interregional integration should take its rightful place in the activities of public administration in order to form an effective regional development policy. This approach will help identify promising areas of interregional cooperation, the formation of new forms and mechanisms of interregional cooperation, and other.

Key words: integration, interregional integration, cooperation, relations, methodological components.

Постановка проблеми. Міжрегіональна інтеграція у сучасних умовах має стати одним із головних напрямів політики регіонального розвитку, забезпечення формування згуртованого простору у соціальному, гуманітарному, економічному, екологічному, безпековому та інших вимірах. Побудова довгострокових, взаємовигідних і рівноправних відносин між регіонами може дати потужний поштовх для соціально-економічного розвитку держави загалом.

Актуальність міжрегіональної інтеграції для підвищення ефективності політики регіонального розвитку зумовлена можливостями зміцнення економічних зв'язків між регіонами, оптимізації побудови інфраструктури на основі спільних цілей розвитку, зменшення фінансових витрат, мінімізації негативного впливу міжрегіональної конкуренції на просування регіонів у глобальному економічному просторі, об'єднання потенціалів регіонів для реалізації міжрегіональних інвестиційних проектів, більш ефективного використання спільних ресурсів, обміну прогресивним досвідом у сфері регіонального розвитку тощо.

Аналіз останніх досліджень і публікацій. Дослідженню аспектів формування та реалізації політики регіонального розвитку, у тому числі такого їі напряму, як міжрегіональна інтеграція, присвячені роботи багатьох науковців. Значна кількість вчених приділяє увагу проблематиці методологічного забезпечення досліджень у сфері побудови інтеграційних зв'язків між регіонами. У цій сфері необхідно відзначити роботи В. Андрійчука, П. Бєлєнького, О. Гонти, М. Долишнього, Ю. Макогона, Н. Мікули, В. Поповкіна, С. Романова, І. Сторонянської, О. Шаблія ін.

Сьогодні різноманітні аспекти міжрегіональної інтеграції досліджуються такими вченими, як О.В. Баула [1], А.П. Безхлібна [2], Є. Волинець [3], Т.В. Деркач [4-6], І.В. Дунаєв [7], М. Лугова [8], Г.О. Мазур [9], М.М. Одінцов [11], Ю.М. Попова [12], Ю.С. Рогозян [14], В.А. Романенко [15], В.І. Юрченко [19], але, враховуючи недостатній рівень використання органами влади можливостей впливу на інтеграційні процеси, які є суттєвим потенціалом для підвищення ефективності політики регіонального розвитку, існує необхідність активізації наукових розвідок у цій сфері.

Метою статті $є$ визначення методологічних складових частин дослідження процесів міжрегіональної інтеграції.

Виклад основного матеріалу дослідження 3 повним обгрунтуванням отриманих наукових результатів. Розглядаючи методологічні аспекти міжрегіональної інтеграції, вбачаємо за необхідне висвітлити деякі особливості розуміння поняття «інтеграція». 
Вперше термін «інтеграція» (від лат. integration - відновлення, поновлення й integer - цілий) застосовано у 30 -х pp. ХХ ст. Підходи деяких науковців до його визначення наведені у таблиці 1 .

Визначення поняття «інтеграція»

Таблиця 1

\begin{tabular}{|c|c|}
\hline Автор & Сутність \\
\hline $\begin{array}{c}\text { Философский } \\
\text { энциклопедический } \\
\text { словарь } \\
\end{array}$ & $\begin{array}{l}\text { Інтеграція - напрямок процесу розвитку, пов'язаний із } \\
\text { об’єднанням у єдине ціле раніше різнорідних частих і } \\
\text { елементів [16]. }\end{array}$ \\
\hline $\begin{array}{l}\text { Тлумачний словник } \\
\text { Оксфордського } \\
\text { університету }\end{array}$ & $\begin{array}{l}\text { Акт чи процес поєднання двох чи більше частин таким чином, } \\
\text { щоб вони функціонували разом [27]. }\end{array}$ \\
\hline К. Пурсіайнен & 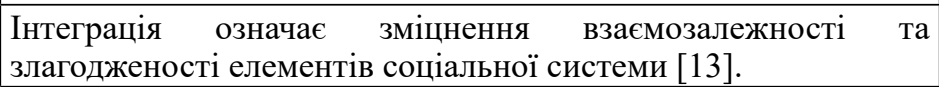 \\
\hline Т. Дієз, А. Вейнер & $\begin{array}{l}\text { Процес, за допомогою якого політичні діячі в особистих } \\
\text { чітких національних установках погоджуються передати свої } \\
\text { довіру, очікування і політичну активність новому центру, } \\
\text { чиї інституції володіють юрисдикцією, яка виходить за межі } \\
\text { раніше існуючої у національних державах [21]. }\end{array}$ \\
\hline Р. Харрісон & $\begin{array}{l}\text { Інтеграція призводить до виникнення нового центру } \\
\text { політичного впливу, що залучає до себе головних суб'єктів } \\
\text { національного масштабу [25]. }\end{array}$ \\
\hline А. Етціоні & $\begin{array}{l}\text { Інтеграція - це певна здатність системи підтримувати себе } \\
\text { саму внаслідок дії та впливу як внутрішніх, так і зовнішніх } \\
\text { змін [22]. }\end{array}$ \\
\hline $\begin{array}{l}\text { П. Якоб, } \\
\text { Дж. Тоскано }\end{array}$ & $\begin{array}{l}\text { Інтеграція - реальна можливість забезпечення мирного } \\
\text { співіснування країн, що досягається шляхом розширення } \\
\text { торгівлі, вільного руху людей, культурного обміну, проведення } \\
\text { консультацій [26]. }\end{array}$ \\
\hline Д. Корби & $\begin{array}{l}\text { Процес, за посередництвом якого окремі держави передають } \\
\text { частину своїх суверенних прав на користь створюваної та } \\
\text { єдиної для них усіх інституціональної структури для того, щоб } \\
\text { забезпечити врахування і реалізацію їх спільних інтересів [20]. }\end{array}$ \\
\hline
\end{tabular}

Таким чином, у сучасних дослідженнях поняття інтеграції пов'язане зі зміцненням взаємозалежності та злагодженості елементів соціальної системи. Термін інтеграція означає певну цілісність, структурованість суспільних відносин, об'єднання людей у нові суспільно-політичні спільноти. Поняття інтеграції має дві основні характеристики: як соціальний процес утворення цілісності (єдності) системи з частин, підсистем, елементів (цілісність системи є більшою, ніж сума її частин); як лояльність стосовно нових учасників процесу, визначення необхідних меж влади.

Основу інтеграції становить міжсистемна взаємодія суспільно-політичної, соціально-економічної, науково-технологічної, соціокультурної сфер суспільного життя.

Відповідно до розуміння сутності інтеграційних процесів, їх природи, спрямованості, специфіки виділяють такі ознаки інтеграції: взаємопроникнення та переплетіння виробничих процесів; широкий розвиток спеціалізації та кооперації у виробництві, науці, техніці на основі найбільш прогресивних їх форм; 
глибокі структурні зрушення в економічних системах інтегрованих утворень; необхідність цілеспрямованого регулювання інтеграційного процесу, розроблення скоординованої економічної стратегії та політики; регіональність територіальних масштабів [17, с. 10-13].

Особливою формою інтеграції, обмеженої територіальними рамками, $\epsilon$ міжрегіональна інтеграція. В умовах глобалізаційних змін значення національних держав зазнає переоцінки. Водночас позиції окремих регіонів у глобалізованому світі суттєво зростають, у тому числі за рахунок розвитку між ними інтеграційних процесів.

Через широке проблемне поле інтеграційних процесів питання міжрегіональної інтеграції розглядаються у науковій літературі з різних позицій із превалюванням досліджень економічної складової частини, у якій науковці виокремлюють низку позитивних ефектів для регіонів, що інтегруються. Серед таких ефектів виділяються економія від масштабу, у тому числі шляхом скорочення транзакційних витрат, а також залучення прямих інвестицій, які роблять регіони-учасники. Інтегровані регіони у торгівельних відносинах впроваджують спрощення процедур, крім того, відбувається розширення обміну досвідом і технологіями, що призводить до спільного розвитку економік регіонів. Одним із головних наслідків економічної інтеграції стає розвиток інтеграційних відносин в інших сферах життєдіяльності регіонів [2; 11].

У роботі [19] також зазначається, що основою будь-якої інтеграції регіонів у межах держави є економічна складова частина, взаємна зацікавленість населення регіонів, підприємств, розташованих на цих територіях, і органів влади, що виражають їхні інтереси, у спільній діяльності, спрямована на вдосконалення умов функціонування і відтворення суспільного капіталу. Такий підхід є загальною умовою, яка реалізується на різних історичних етапах, у різному соціально-культурному контексті. Кооперація регіональних підсистем може у зв'язку 3 цим істотно відрізнятися у різних державах, залежати від історичних традицій, системи територіального розміщення виробництва, диференціації рівнів економічного розвитку регіонів і ступеня їх забезпечення трудовими і матеріальними, у тому числі сировинними, ресурсами, що склалася.

У рамках дослідження економічної складової частини міжрегіональної інтеграції науковці проводять аналіз обміну продукцією виробничо-технічного призначення між областями України, результатами якого є встановлення регіонів-лідерів за обсягами обміну продукцією й особливостей міжрегіонального обміну. Також досліджується вплив галузевих особливостей промисловості на характер міжрегіонального обміну. Виявлено, що обробна промисловість, зокрема машинобудування, набагато ширше залучена до міжрегіонального обміну, ніж добувна, й оцінюється поточний стан і тенденції обміну продукцією виробничо-технічного призначення [15].

Значна кількість публікацій присвячена дослідженню взаємозв'язків рівнів міжрегіональної взаємодії й інноваційної активності в інтегрованих регіонах. У роботах $[23 ; 24 ; 31]$, встановлено, що наявність стійких міжрегіональних зв'язків сприяє підвищенню рівня інноваційної активності у регіонах. Вчені вважають основними перевагами міжрегіональної взаємодії активізацію розвитку інновацій, котрі сприяють більш широким можливостям ринку праці та збільшенню інформаційних потоків.

У статті [1] обгрунтовано актуальність активізації міжрегіонального співробітництва в інноваційній сфері, оскільки вона сприяє нівелюванню диспропорцій 
інноваційного розвитку в країні, а також формуванню ефективного та цілісного інноваційного простору. Встановлено, що ефективність управління інноваційними процесами на регіональному рівні залежить від обліку змін, які відбуваються на макрорівні, а саме від обраної моделі інноваційного розвитку. Також окреслюються принципи міжрегіональної інтеграції інноваційних процесів.

Науковцями розкриваються теоретико-методичні засади формування політики міжрегіональної економічної інтеграції та проводиться оцінка ефективності економічної інтеграції на міжрегіональному рівні як ресурсу регіонального розвитку. Досліджуються позитивні та негативні наслідки реалізації економічної інтеграції на загальносвітовому, загальнодержавному та міжрегіональному рівнях. Крім того, висвітлюються підходи до оцінки ефективності економічної інтеграції на міжрегіональному рівні. Пропонуються методичні підходи до визначення рівня міжрегіональних інтеграційних процесів і набір показників, що характеризують рівень інтеграційних процесів на рівні регіону, серед яких: товарообіг; обсяг і структура інвестицій; обсяг споживаної електроенергії, яка надходить із інших регіонів [6].

Науковці відзначають, що міжрегіональні зв'язки мають значний вплив на процес залучення іноземного капіталу в економіку країни та забезпечення інвестиційної привабливості не лише регіонів, але й України загалом [8].

У сфері аналізу закордонного досвіду міжрегіонального економічного співробітництва науковці приділяють увагу виявленню сучасних тенденцій створення та функціонування міжрегіональних інтеграційних об'єднань [14].

У низці робіт міжрегіональна взаємодія розглядається у контексті глобалізації як одного з основних напрямів розвитку сучасної економіки та суспільства. Вчені під глобалізацією розуміють інтеграційний процес, що відображає взаємозалежність держав на міжнародній арені в усіх сферах своєї діяльності: економічної, політичної, соціальної, культурної, інформаційної та ін. Залежність міжрегіональної взаємодії та глобалізації визначається через те, що чим більш глобальними стають відносини, тим більшою невизначеністю вони характеризуються. У таких умовах об'єднаним суб'єктам господарювання набагато простіше протистояти міжнародній конкуренції [28-30].

Ще одним аспектом досліджень міжрегіональної взаємодії $є$ розвиток міжнародних зв'язків [12]. Виявлена низка позитивних факторів, які є наслідками інтеграційних процесів: розвиток мереж співпраці в економічній, політичній, академічній, соціальній і культурній сферах та більш ефективні процеси інтеграції регіонів України у єдиний європейський простір.

Проведений аналіз літературних джерел дозволяє стверджувати, що міжрегіональна інтеграція $\epsilon$ універсальним, складним і багатоаспектним процесом, тому виникає необхідність формування теоретико-методологічного підгрунтя для наукового забезпечення діяльності органів публічного управління у сфері побудови оптимальних міжрегіональних зв'язків.

Згідно з поглядами I.В. Дунаєва методологічно міжрегіональна інтеграція та співробітництво формують такі рамки для модернізації політики регіонального розвитку:

- важливість у сучасному процесі публічного управління регіональним розвитком;

- орієнтир на самодостатній розвиток, що послаблює ізоляцію як сильних, так і слабких регіонів, проте відбувається поляризація груп регіонів між собою за рівнем самого розвитку і на основі передовсім економічних вигід; 
- подолання внутрішньої неподільності регіонів і зовнішніх протидій, що $є$ рушійною силою регіонального розвитку. Відсутність спільного кордону та самі адміністративні кордони регіонів втрачають значення;

- пошук і реалізація «великого імпульсу» розвитку ефективно здійснюються завдяки зусиллям як самих регіонів, так і держави;

- єдність мотивації розвитку слабких і сильних регіонів створюється імперативами розвитку та формуванням мезосистем, що характеризуються єдиними критеріями;

- конструювання мезосистем у системі механізму управління регіональним розвитком передбачає єдність принципів;

- міжрегіональні зв'язки розвиваються у мережевій спосіб організації форм співробітництва й інститутів міжрегіональної інтеграції [7].

На нашу думку, методологічно міжрегіональна інтеграція має включати сутність, принципи, суб'єкти й об'єкти, головні фактори розвитку міжрегіональної інтеграції, основні напрями, а також форми та механізми міжрегіональної взаємодіï, у тому числі ії інституційно-правове забезпечення.

Сутністю міжрегіональної інтеграції є забезпечення оптимального соціально-економічного розвитку регіонів в аспекті вирішення територіальних проблем міжрегіонального характеру на основі збалансованого поєднання інтересів і ресурсів держави, регіону, бізнесу і громадськості за принципами демократичного врядування шляхом формування єдиного соціально-економічного простору й усунення перешкод, які виникають на шляху міжрегіональних потоків, стимулювання їх мобільності [3].

Основні принципи міжрегіональної інтеграції включають ділове партнерство, адаптивність, системність, прагматизм, субсидіарність, співфінансування, цілеспрямованість, поступовість, добровільність, рівність регіонів у взаємодії, прозорість, легітимність інтересів регіонів, динамічність, погодженість інтересів державних і регіональних органів влади [3; 4].

Міжрегіональна інтеграція уявляється як багаторівневий процес взаємодії регіонів, у якому чітко виділяються такі рівні: регіональний; місцевий; рівень підприємств і бізнес-структур. Відповідно, основними суб' єктами реалізації інтеграційних програм стають: регіональні органи влади; місцеві органи влади; підприємства, компанії, банки й інші бізнес-структури, інститути громадянського суспільства [5].

На окрему увагу заслуговують питання визначення об'єктів міжрегіональної інтеграції. Загальновідомо, що об'єктом наукового дослідження є навколишній матеріальний світ і форми його відображення у людській свідомості, які існують незалежно від нашої свідомості, вибрані відповідно до мети дослідження. Залежно від ступеня складності виділяють прості та складні об'єкти дослідження, відмінність між ними визначена кількістю елементів і видом зв'язку між ними $[18$, c. 24$]$.

Таким чином, об’єкти міжрегіональної інтеграції мають складний характер через те, що під час дослідження процесів взаємодії між регіонами треба визначити вплив численних факторів на кінцевий результат - побудову нових інтегративних зв'язків між підсистемами й елементами двох або більше регіональних системних утворень.

Отже, об'єктами міжрегіональної інтеграції є розвиток економічних і соціально-гуманітарних зв'язків між регіонами, вплив дій органів влади на інтеграційні процеси. 
У науковій літературі зустрічаються дослідження, присвячені аналізу чинників взаємодії територій. Вчені виділяють такі фактори, що сприяють цьому процесу:

- традиції культурно-гуманітарної взаємодії, що згодом посилюються ще і торговельно-економічною взаємодією між регіонами;

- доступність базових і сучасних благ і послуг;

- наявність системи якісного й інтегрованого стратегічного планування тих сфер, які можуть впливати на регіональний розвиток;

- реальне місце регіону в міжрегіональному поділі праці. В умовах конкуренції майже на всіх рівнях і за відсутності просторових і юридичних перешкод праця перетікає з відсталих регіонів до більш розвинених [7].

На наш погляд, наведений перелік чинників має бути доповнений факторами спільного використання регіонами інфраструктури, у тому числі енергетичної, транспортної та ін.; спільного використання розробок науково-дослідних організацій; спільного використання природно-ресурсного потенціалу регіонів.

На основі вищенаведеного аналізу наукової літератури можна виділити основні напрями міжрегіональної інтеграції:

- взаємний товарообмін;

- виробничі зв’ язки на основі спеціалізації та кооперації;

- взаємодія у сфері фінансів і кредиту;

- співпраця у сфері науково-технічної діяльності й інновацій;

- взаємодія у сфері інвестиційної діяльності;

- спільне освоєння і використання природних ресурсів;

- територіальний перерозподіл і використання трудових ресурсів;

- спільне формування та використання інформаційних систем.

Наведені напрями міжрегіональної інтеграції здебільшого відображають тільки економічний зміст взаємодії між регіонами. Враховуючи комплексний характер інтеграційних процесів, розвиток міжрегіональної інтеграції також відбувається і в інших сферах, серед яких:

- співпраця у сфері розвитку інфраструктури міжрегіонального співроробітництва (транспорт, зв'язок, енергетика, торгово-промислові та виставкові центри та ін.);

- співпраця у соціальній сфері (у сфері соціального захисту, охорони здоров'я);

- взаємодія у сфері екології, попередження і ліквідації стихійних лих і техногенних катастроф;

- системний розвиток гуманітарних зв'язків (наукових, освітніх, культурних, у сфері молодіжного співробітництва, туризму і спорту);

- координація дій регіональних органів влади щодо впливу на інтеграційні процеси.

Серед форм міжрегіональної інтеграції можна виділити: міжрегіональні кластери; території пріоритетного розвитку, спеціальні вільні зони, міжрегіональні транспортні коридори, асоціації економічної взаємодії; державну підтримку міжрегіональних інфраструктурних проєктів; надання підприємствам субсидій і пільг; надання кредитів за заниженою ставкою; фінансову підтримку при придбанні патентів і ліцензій; розвиток науково-технічних розробок; інформаційне супроводження інноваційних проектів; розвиток інфраструктури (логістичної, інженерної й т.д.); розвиток електронної торгівлі у секторі b2b; формування єдиної інформаційної бази за підприємствами.

Механізми міжрегіональної інтеграції об’єднують інституційне впорядкування нових форм відносини між регіонами, узгодження інтересів, перерозподіл ресурсів, стратегічне управління [3; 4;9]. 
3 методологічного погляду, особливо у сфері публічного управління регіональним розвитком, треба зазначити, що сучасні процеси міжрегіональної інтеграції мають будуватися на основі визначення об'єднуючих засад і забезпечення координованості дій всіх суб'єктів взаємодії. Такий підхід дозволяє визначити міжрегіональну інтеграцію як внутрішньоскоординований розвиток регіональних системних утворень через встановлення зв'язків між їх підсистемами з метою ефективного об'єднання розрізнених структур і процесів у структуровану динамічну систему інтегративної взаємодії. В умовах сьогодення сучасним тенденціям інтегративних процесів найбільш відповідає побудова мережевих форм організації встановлення міжрегіональних зв'язків. Таким чином, наведене дозволяє нам представити твердження, що міжрегіональна інтеграція є інноваційним напрямом політики регіонального розвитку, й ефективність інтеграційних процесів задається і регулюється системним і цілеспрямованим впливом органів публічного управління на встановлення економічних, соціально-гуманітарних та інших зв'язків між регіонами.

Висновки. Використання розглянутих методологічних складових частин міжрегіональної інтеграції має посісти належне місце у діяльності органів публічного управління 3 метою формування ефективної політики регіонального розвитку. Такий підхід сприятиме визначенню перспективних напрямів міжрегіонального співробітництва, становленню нових форм і механізмів міжрегіональної взаємодії та ін.

Удосконалення системи наукових знань про взаємодію головних суб'єктів міжрегіональної інтеграції та про способи їх впливу на інтеграційні процеси має підвищити результативність публічного управління регіональним розвитком. Треба розглядати як домінантний підхід, за яким взаємодія органів публічного управління національного та регіонального рівнів $€$ головним інтеграційним чинником для регіональних системних утворень.

\section{СПИСОК ВИКОРИСТАНОЇ ЛІТЕРАТУРИ:}

1. Баула О.В. Концептуальні засади міжрегіональної інтеграції у розвитку інноваційних процесів. Економічні науки. Серія : Регіональна економіка. 2020. Вип. 17. C. 23-32.

2. Безхлібна А.П. Наукові засади дослідження процесів міжрегіональної інтеграції як чинника підвищення конкурентоспроможності. Науковий вісник Мукачівського державного університету. Серія : Економіка. 2019. Вип. 1. С. 60-65.

3. Волинець С. Стратегія міжрегіональної інтеграції як механізм демократизації врядування на регіональному рівні. Актуальні проблеми державного управління. 2010. Вип. 3 (2). С. 46-49.

4. Деркач Т.В. Важелі й механізми управління інтеграційними процесами у регіональному економічному просторі. Науковий вісник Ужгородського національного університету. Серія : Міжнародні економічні відносини та світове господарство. 2016. Вип. 8 (1). С. 62-66.

5. Деркач Т.В. Концептуальні засади формування моделі міжрегіональної інтеграційної взаємодії. Математичні методи, моделі та інформаційні технологї в економіці. 2016. № 6. С. 197-201.

6. Деркач Т. Оцінка ефективності економічної інтеграції на міжрегіональному рівні як ресурсу регіонального розвитку. Вісник Тернопільського національного економічного університету. 2016. Вип. 3. С. 37-49.

7. Дунаєв І.В. Вплив інтеграційних процесів на модернізацію регіональної економічної політики. Теорія та практика державного управління. 2016. Вип. 1. C. $116-125$. 
8. Лугова М. Міжрегіональна інтеграція як чинник активізації інвестиційної діяльності в регіоні. Науковий вісник Східноєвропейського наиіонального університету імені Лесі Українки. Міжнародні відносини. 2013. № 9. С. 13-18.

9. Мазур Г.О. Особливості сучасних міжрегіональних інтеграційних процесів та їх основні тенденції територіальної організації макроструктури. Економіка $i$ регіон. 2014. № 2. С. 29-34.

10. Модели современных интеграционных процессов. URL: http://www.Xserver. ru/user/msipr/ (дата звернення: 10.11.2021).

11. Одінцов М.М. Вплив інтеграційних процесів на розвиток міжрегіональних продовольчих зв'язків. Агросвіт. 2010. № 6. С. 14-16.

12. Попова Ю.М., Радченко Л.М., Якушенко С. Міжрегіональне співробітництво України та республіки Польща у контексті інтеграції України до СС. Економічний простір. 2016. № 106. С. 36-44.

13. Пурсиайнен К. От слов - к делу (теории интеграции). Современная Европа. 2005. № 2. C. 23-38.

14. Рогозян Ю.С. Міжрегіональне співробітництво як форма економічної інтеграції: закордонний досвід. Вісник Дніпропетровського університету. Серія : Економіка. 2016. Т. 24. Вип. 10 (1), С. 122-126.

15. Романенко В.А., Лазебна І.В. Міжрегіональна інтеграція в промисловості як чинник формування економічного простору України. Економіка та держава. 2019. № 3. С. 10-15.

16. Философский энциклопедический словарь / гл. ред. : Л.Ф. Ильичёв, П.Н. Федосеев, С.М. Ковалёв, В.Г. Панов. Москва : Советская энциклопедия, $1983.840 \mathrm{c}$.

17. Філософія інтеграції: монографія / за заг. ред. В.Д. Бондаренка, Ф.Г. Ващука. Ужгород : ЗакДУ, 2011. 544 с.

18. Чмиленко Ф.О., Жук Л.П. Посібник до вивчення дисципліни «Методологія та організація наукових досліджень». Дніпро : РВВ ДНУ, 2014. 48 с.

19. Юрченко B.I. Макроекономічна політика сприяння міжрегіональній економічній інтеграції в напрямку розвитку національної економіки. Державне управління: удосконалення та розвиток. 2012. № 11. URL: http://nbuv.gov.ua/UJRN/ Duur 2012116

20. Corbey, D. Dialectical functionalism: stagnation as a booster of European integration. International organization. 1995. Vol. 49. № 2. P. 253-284.

21. Diez, T., Wiener, A. Introducing the Mosaic of Integration Theory: It's Past, Present and Future. Paper for presentation at the European Union Studies Association (EUSA) 8th Biennial International Conference. Mar. 27-29. 2003. Nashville. TN, Panel 8H (Unpublished). 27 p. Archive of European integration (AEI). URL: http://aei.pitt. edu/2858/1/107.pdf.

22. Etzioni, A. Political unification: a comparative study of leaders and forces. New York : Rinehart, 1965. 346 p.

23. Fritsch, M. Does R\&D-cooperation behavior differ between regions? Industry and Innovation. 2003. Vol. 10, № 1. P. 25-39.

24. Fritsch, M., Lukas, R. Innovation, cooperation and the region Innovation, Industry Evolution and Employment. 1999. P. 157-181.

25. Harrison, R. Europe in question: theories of regional international integration. London: George Allen \& Unwin Ltd., 1974. 256 p.

26. Jacob, P., Toscano, J. The integration of political Communities. Philadelphia : Lippincott, 1964. 314 p.

27. Oxford Advanced Learner's Dictionary of Current English / Sixth Edition ; ed. by Sally Wehmeier. Oxford : University Press. 2000, 1540 p.

28. Reiterer, M. Interregionalism as a new diplomatic tool: the EU and East Asia. EFAR. 2006. № 11. P. 242.

29. Song, W. Regionalization, inter-regional cooperation and global governance. Asia Europe Journal. 2007. vol. 5 (1). P. 67-82. 
30. Torre, A. Rallet, A. Proximity and Localization. Regional Studies. 2005. Vol. 39. № 1. P. 47-59.

31. Zhao, S., Cacciolatti, L., Lee, S., Song, W. Regional collaborations and indigenous innovation capabilities in China: A multivariate method for the analysis of regional innovation systems. Technological Forecasting and Social Change. 2015. Vol. 94. P. 202-220.

\section{REFERENCES:}

1. Baula, O.V. (2020). Konceptual'ni zasady' mizhregional'noyi integraciyi u rozvy'tku innovacijny'h procesiv [Conceptual principles of interregional integration in the development of innovation processes]. Ekonomichni nauky'. Seriya : Regional'na ekonomika, 17, 23-32 [in Ukrainian].

2. Bezkhlibna, A.P. (2019). Naukovi zasady doslidzhennya protsesiv mizhrehional'noyi intehratsiyi yak chynnyka pidvyshchennya konkurentospromozhnosti [Scientific bases of research of processes of interregional integration as a factor of increase of competitiveness]. Naukovyy visnyk Mukachivs'koho derzhavnoho universytetu. Ser. : Ekonomika. 1, 60-65 [in Ukrainian].

3. Volynets', Ye. (2010). Ctratehiya mizhrehional'noyi intehratsiyi yak mekhanizm demokratyzatsiyi vryaduvannya na rehional'nomu rivni [Strategy of interregional integration as a mechanism for democratization of governance at the regional level]. Aktual'ni problemy derzhavnoho upravlinnya. 3 (2), 46-49 [in Ukrainian].

4. Derkach, T.V. (2016). Vazheli y mekhanizmy upravlinnya intehratsiynymy protsesamy u rehional'nomu ekonomichnomu prostori [Levers and mechanisms of management of integration processes in the regional economic space]. Naukovyy visnyk Uzhhorods'koho natsional'noho universytetu. Seriya : Mizhnarodni ekonomichni vidnosyny ta svitove hospodarstvo. 8 (1), 62-66 [in Ukrainian].

5. Derkach, T.V. (2016). Kontseptual'ni zasady formuvannya modeli mizhrehional'noyi intehratsiynoyi vzayemodiyi [Conceptual bases of formation of model of interregional integration interaction]. Matematychni metody, modeli ta informatsiyni tekhnolohiyi v ekonomitsi. 6, 197-201 [in Ukrainian].

6. Derkach, T. (2016). Otsinka efektyvnosti ekonomichnoyi intehratsiyi na mizhrehional'nomu rivni yak resursu rehional'noho rozvytku [Evaluation of the effectiveness of economic integration at the interregional level as a resource for regional development]. Visnyk Ternopil's'koho natsional'noho ekonomichnoho universytetu. 3, 37-49 [in Ukrainian].

7. Dunayev, I.V. (2016). Vplyv intehratsiynykh protsesiv na modernizatsiyu rehional'noyi ekonomichnoyi polityky [The impact of integration processes on the modernization of regional economic policy]. Teoriya ta praktyka derzhavnoho upravlinnya. 1, 116-125 [in Ukrainian].

8. Luhova, M. (2013). Mizhrehional'na intehratsiya yak chynnyk aktyvizatsiyi investytsiynoyi diyal'nosti $\mathrm{v}$ rehioni [Interregional integration as a factor in intensifying investment activities in the region]. Naukovyy visnyk Skhidnoyevropeys'koho natsional'noho universytetu imeni Lesi Ukrayinky. Mizhnarodni vidnosyny. 9, 13-18 [in Ukrainian].

9. Mazur, H.O. (2014). Osoblyvosti suchasnykh mizhrehional'nykh intehratsiynykh protsesiv ta yikh osnovni tendentsiyi terytorial'noyi orhanizatsiyi makrostruktury [Features of modern interregional integration processes and their main trends in the territorial organization of macrostructure]. Ekonomika i rehion. 2, 29-34 [in Ukrainian].

10. Modeli sovremennykh integracionnykh processov [Models of modern integration processes]. URL: http://www.Xserver.ru/user/msipr/ (Last accessed: 10.11.2021) [in Russian].

11. Odintsov, M.M. (2010). Vplyv intehratsiynykh protsesiv na rozvytok mizhrehional'nykh prodovol'chykh zvyazkiv [The impact of integration processes on the development of interregional food relations]. Ahrosvit. 6, 14-16 [in Ukrainian]. 
12. Popova, Yu.M., Radchenko L.M., Yakushenko S. (2016). Mizhrehional'ne spivrobitnytstvo Ukrayiny ta respubliky Pol'shcha u konteksti intehratsiyi Ukrayiny do YES [Interregional cooperation between Ukraine and the Republic of Poland in the context of Ukraine's integration into the EU]. Ekonomichnyy prostir. 106, 36-44 [in Ukrainian].

13. Pursiaynen, K. (2005). Ot slov - k delu (teorii integratsii) [From words to deeds (integration theory)]. Sovremennaya Yevropa. 2, 23-38 [in Russian].

14. Rohozyan, Yu.S. (2016). Mizhrehional'ne spivrobitnytstvo yak forma ekonomichnoyi intehratsiyi: zakordonnyy dosvid [Interregional cooperation as a form of economic integration: foreign experience]. Visnyk Dnipropetrovs'koho universytetu. Seriya : Ekonomika. 10 (1), 122-126 [in Ukrainian].

15. Romanenko, V.A., Lazebna, I.V. (2019). Mizhrehional'na intehratsiya v promyslovosti yak chynnyk formuvannya ekonomichnoho prostoru Ukrayiny [Interregional integration in industry as a factor in shaping the economic space of Ukraine]. Ekonomika ta derzhava. 3, 10-15 [in Ukrainian].

16. Il'ichov, L.F. (Eds.) (1983). Filosofskiy entsiklopedicheskiy slovar' [Philosophical Encyclopedic Dictionary]. Moskva: Sovetskaya entsiklopediya [in Russian].

17. Bondarenko, V.D. (Eds.) (2011). Filosofiya intehratsiyi: monohrafiya [Philosophy of integration: a monograph]. Uzhhorod: ZakDU [in Ukrainian].

18. Chmylenko F.O., Zhuk L.P. (2014). Posibnyk do vyvchennya dystsypliny "Metodolohiya ta orhanizatsiya naukovykh doslidzhen" [Manual for the study of the discipline "Methodology and organization of scientific research"]. Dnipro: RVV DNU [in Ukrainian].

19. Yurchenko V.I. (2012). Makroekonomichna polityka spryyannya mizhrehional'niy ekonomichniy intehratsiyi v napryamku rozvytku natsional'noyi ekonomiky [Macroeconomic policy to promote interregional economic integration in the direction of national economy development]. Derzhavne upravlinnya: udoskonalennya ta rozvytok. 11, URL: http://nbuv.gov.ua/UJRN/Duur 2012 11 6 (Last accessed: 10.11.2021) [in Ukrainian].

20. Corbey, D. Dialectical functionalism: stagnation as a booster of European integration. International organization. 1995. Vol. 49. № 2. P. 253-284.

21. Diez, T., Wiener, A. Introducing the Mosaic of Integration Theory: It's Past, Present and Future. Paper for presentation at the European Union Studies Association (EUSA) 8th Biennial International Conference. Mar. 27-29. 2003. Nashville. TN, Panel $8 \mathrm{H}$ (Unpublished). 27 p. Archive of European integration (AEI). URL: http://aei.pitt. edu/2858/1/107.pdf.

22. Etzioni, A. Political unification: a comparative study of leaders and forces. New York : Rinehart, 1965. 346 p.

23. Fritsch, M. Does R\&D-cooperation behavior differ between regions? Industry and Innovation. 2003. Vol. 10, no. 1. P. 25-39.

24. Fritsch, M., Lukas, R. Innovation, cooperation and the region Innovation, Industry Evolution and Employment. 1999. P. 157-181.

25. Harrison, R. Europe in question: theories of regional international integration. London : George Allen \& Unwin Ltd., 1974. 256 p.

26. Jacob, P., Toscano, J. The integration of political Communities. Philadelphia : Lippincott, 1964. 314 p.

27. Oxford Advanced Learner's Dictionary of Current English / Sixth Edition ; ed. by Sally Wehmeier. Oxford : University Press. 2000, 1540 p.

28. Reiterer, M. Interregionalism as a new diplomatic tool: the EU and East Asia. EFAR. 2006. № 11. P. 242.

29. Song, W. Regionalization, inter-regional cooperation and global governance. Asia Europe Journal. 2007. vol. 5 (1). P. 67-82.

30. Torre, A. Rallet, A. Proximity and Localization. Regional Studies. 2005. Vol. 39. \# 1. P. 47-59.

31. Zhao, S., Cacciolatti, L., Lee, S., Song, W. Regional collaborations and indigenous innovation capabilities in China: A multivariate method for the analysis of regional innovation systems. Technological Forecasting and Social Change. 2015. Vol. 94. P. 202-220. 